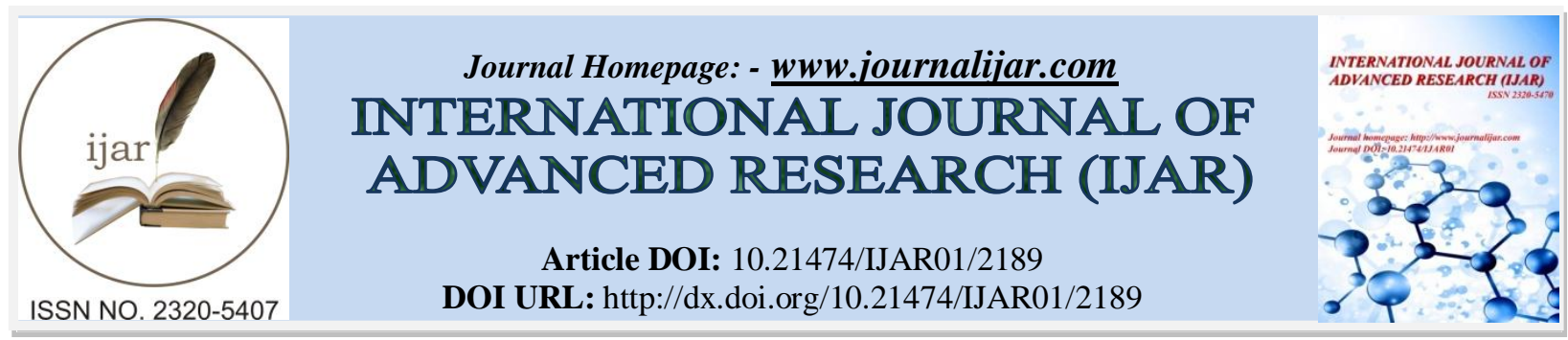

RESEARCH ARTICLE

\title{
MONITORING VIRULENCE PATTERNS OF XANTHOMONAS ORYZAE PV. ORYZAE IN TERAI REGION OF NEPAL.
}

\author{
Ram Bahadur Khadka ${ }^{1}$, Bedanand Chaudhary ${ }^{2}$, Narayan Pathak ${ }^{1}$, Prakash Pantha ${ }^{2}$, Casiana M. Vera Cruz ${ }^{3}$, \\ Uma Shankar Singh ${ }^{4}$, Najam Waris Zaidi ${ }^{4}$ and Bhaba Prasad Tripathi ${ }^{5}$. \\ 1. Nepal Agricultural Research Council (NARC), Regional Agricultural Research Station (RARS), Khajura, \\ Nepalgunj, Banke, Nepal. \\ 2. National Rice Research Program (NRRP), Hardinath, Dhanusha, NARC, Nepal. \\ 3. IRRI, Los Banos, Philippines. \\ 4. IRRI-India Office, New Delhi, India. \\ 5. IRRI-Nepal Office, Singhdurbar Plaza, Kathmandu, Nepal.
}

\section{Manuscript Info}

Manuscript History

Received: 27 September 2016

Final Accepted: 30 October 2016

Published: November 2016

Key words:-

Bacterial blight, effective Xa genes,

isolates, near-isogenic lines, Nepal

Terai, virulence pattern

\section{Abstract}

Bacterial blight (BB) of rice, caused by Xanthomonas oryzae pv. oryzae (Xoo), is one of the destructive rice diseases in Nepal. Use of host plant resistance is the most effective method of $\mathrm{BB}$ management. However, breakdown of resistance of a variety often occurs after few years of release due to genetic adaptation of the pathogen. So, understanding of pathogen population virulence is required to deploy a suitable variety with effective gene in the target areas. Considering the point, BB isolates were collected from five different districts of Nepal Terai during 2012-2013 and were tested on BB near-isogenic lines during 2014 at Regional Agricultural Research Station, Khajura, Nepalgunj, Banke, Nepal. The occurrence of BB pathogen was highly variable and diverse on the tested genotypes and over locations. No single gene showed resistance to all the $\mathrm{BB}$ pathogen population available in Nepal Terai. Xa21 was effective to isolates of Bardiya, Banke, Kailali, and Morang except to the isolate from Rupandehi. The $\mathrm{BB}$ pathogen from Rupandehi was the most virulent to all single genes except Xa3; and also to two gene pyramids (IRBB-50, IRBB-51, IRBB-53, IRBB-54 and IRBB-55). Three gene-, four- and five genepyramids were resistant to all isolates of five different locations. IR-24 got the longest lesion length and could be used as susceptible check in the screening nursery. Thus, three genes or four genes combination could be deployed for stable management of BB disease and minimize crop losses.

Copy Right, IJAR, 2016,. All rights reserved.

\section{Introduction:-}

Bacterial blight (BB) of rice (Oryza sativa L.), caused by Xanthomonas oryzae pv. oryzae (Xoo), is a major threat to rice production in Asia (Mew, 1987; -, 1989) and, in particular, Nepal (Manandhar, 1987; Adhikari and Mew, 1991; Dangal et al., 2014; Chaudhary et al., 2015). The disease is widely distributed in the hills and plains of Nepal

Corresponding Author:- Bedanand Chaudhary.

Address:- National Rice Research Program (NRRP), Hardinath, Dhanusha, NARC, Nepal. 
(Manandhar et al., 1987; Adhikari and Shrestha, 1989; Adhikari and Mew, 1994). The disease was reported as early as 1965 in Kathmandu Valley (Khadka et al., 1968) and it spread rapidly in subsequent years and is now prevalent throughout the Terai belts (plain) and hills. Yield losses, estimated up to $26 \%$, have been recorded, with the greatest destruction being during the Kresek phase" of the disease, usually occurring 2-3 weeks after transplanting (IRRI, 1979; Adhikari et al., 1990). The occurrence of the disease in Terai is usually early in the season (Adhikari et al., 1990). Major epidemics were reported in 1979 (IRRI, 1979), in 1987 (Adhikari and Shrestha, 1989) and in 2014 (RARS, 2014). Disease management through chemicals and other agronomic management practices are not always practical and cost effective. Use of resistant varieties for its management is the most effective and sustainable means.

However, the resistant varieties become susceptible after few years of release due to development and dominance of virulence races in the pathogenic population (Mew et al., 1992; Adhikari et al., 1994). For instance, breaking down of resistance of IRBB-21 rice line harbouring dominant gene Xa21 by some of Xoo isolates from Japan, Nepal, Korea and India have been reported in earlier studies (Lin et al., 1996; Adhikari et al., 1999). Information to understand the virulence of Xoo pathogen is necessary to determine effective bacterial blight resistance gene. In this study, isolates from five different Terai districts were tested in BB near isogenic lines at Regional Agricultural Research Station (RARS), Khajura, Nepalgunj during 2012-2013 and 2014.

\section{Materials and Methods:- Sampling:-}

A comprehensive BB disease survey and samplings were carried out in five major rice producing districts of Terai region of Nepal during wet season of 2012-13. The survey was carried out in five districts of eastren, central, mid western and far-westren development regions of Nepal viz. Morang, Rupandehi, Banke, Bardiya and Kailali.

\section{Isolation and confirmation of bacteria:-}

The collected leaf samples were taken to the Plant Pathology Laboratory of RARS, Khajura and disease was confirmed by observing the oozing under compound microscope (OLYMPUS, BX51). Bacteria were isolated from infected rice leaves by following the method of Adhikari et al. (1995). Bacteria having yellow circular colonies with entire margins and smooth waxy and shiny surfaces were isolated. Single bacterial colonies of each strain were isolated. The isolated colonies were further purified on peptone sucrose agar (PSA) medium. Afterwards bacterial cells were preserved in 5\% skimmed milk and PSA slants at $4^{\circ} \mathrm{C}$ as a source for further work. The bacterial strains were then inoculated on the susceptible rice variety $\mathrm{TN}-1$ to verify their pathogenicity.

\section{Near-isogenic rice lines:-}

Seeds of the near-isogenic rice lines (NILs) and IR-24 were obtained from International Rice Research Institute, Philippines. The experiment for testing of Xoo isolates on NILs was undertaken during August-September 2014 at RARS, Khajura, Banke. The 20 NILs with single and different $X a$ gene combinations were used in the experiment (Table 1). IR-24 was used as the susceptible check. Rice seeds were first placed in petri-plates and kept in incubator for germination. After five days of incubation, three healthy seedlings of each line were transferred to 100 -cm plastic buckets and were kept in glass house. The buckets were filled with mixture of soil and farmyard manure (1:1). Moreover $10 \mathrm{~g}$ mixture of nitrogen, phosphorus and potassium in the form of urea, di-ammonium phosphate and muriate of potash was added to each bucket. The plants were watered every day and $5 \mathrm{~g}$ urea was added 30 days after transplanting to each bucket.

\section{Inoculum preparation:-}

The strains of $X$. oryzae pv. oryzae isolated from the foliar samples of rice were incubated in PSA slants at $28^{\circ} \mathrm{C}$ for 72 hours. The three day old cultures were then used to prepare inoculum. Inoculum was prepared by suspending the bacterial cells of each strain in $10 \mathrm{ml}$ of sterile distilled water separately and adjusting the concentration up to $10^{8}$ colony forming units $(\mathrm{CFU}) / \mathrm{ml}$ by maintaining transparency around $50 \%$ which was measured by Spectrophotometer (Single Monochromator UV-2600).

\section{Inoculation:-}

To test the virulence of bacterial strains on the NILs, the experiment was designed in a split plot design. The NILs were considered as the main plot and bacterial isolates as sub plots (Gomez \& Gomez, 1984). Thus, the experimental unit consisted of 3 plants per strain inoculation (Adhikari et al., 1999). Three plants of each NIL were inoculated with each of the strains of $X$. oryzae pv. oryzae using clip inoculation method 25 days after seeding 
(Kauffman et al., 1973). For this purpose 1 to $2 \mathrm{~cm}$ of the tips of three fully expanded leaves of each plant in each bucket (total of nine leaves per strain inoculation) were clipped with scissors dipped in inoculum. Control plants were inoculated similarly with sterilized distilled water.

\section{Estimation of infection:-}

After 14 days of inoculation the lesion length was measured in centimeters from the cuts of leaf tips (Mew et al., 1989). Resistance or susceptibility was assessed from the mean lesion length of the nine inoculated leaves of each NILs. Reactions of lines were categorized according to lesion length, where 0 to $3 \mathrm{~cm}$ length was classified as resistant (R) and more than $3 \mathrm{~cm}$ as susceptible (S) (Adhikari et al., 1999).

\section{Results and Discussions:-}

Table 1:- Reaction of bacterial blight near-isogenic lines to bacterial blight isolates of five different locations tested at RARS, Khajura, Banke, Nepal during 2014

\begin{tabular}{|c|c|c|c|c|c|c|}
\hline NILs/Pyramid lines & $X a$-gene(s) & Bardiya & Banke & Kailali & Morang & Rupandehi \\
\hline IRBB-1 & $X a 1$ & $\mathrm{R}$ & $\mathrm{S}$ & $\mathrm{S}$ & $\mathrm{S}$ & $\mathrm{S}$ \\
\hline IRBB-3 & $X a 3$ & $\mathrm{~S}$ & $\mathrm{R}$ & $\mathrm{R}$ & $\mathrm{S}$ & $\mathrm{R}$ \\
\hline IRBB-4 & $X a 4$ & $\mathrm{R}$ & $\mathrm{S}$ & $\mathrm{R}$ & $\mathrm{R}$ & $\mathrm{S}$ \\
\hline IRBB-7 & $X a 7$ & $\mathrm{R}$ & $\mathrm{R}$ & $\mathrm{S}$ & $\mathrm{S}$ & $\mathrm{S}$ \\
\hline IRBB-13 & $x a 13$ & $\mathrm{~S}$ & $\mathrm{~S}$ & $\mathrm{R}$ & $\mathrm{S}$ & $\mathrm{S}$ \\
\hline IRBB-14 & $X a 14$ & $\mathrm{~S}$ & $\mathrm{~S}$ & $\mathrm{~S}$ & $\mathrm{~S}$ & $\mathrm{~S}$ \\
\hline IRBB-21 & $X a 21$ & $\mathrm{R}$ & $\mathrm{R}$ & $\mathrm{R}$ & $\mathrm{R}$ & $\mathrm{S}$ \\
\hline IR-24 & $X a 18$ & $\mathrm{~S}$ & $\mathrm{~S}$ & $\mathrm{~S}$ & $\mathrm{~S}$ & $\mathrm{~S}$ \\
\hline IRBB-50 & $X a 4+x a 5$ & $\mathrm{R}$ & $\mathrm{R}$ & $\mathrm{R}$ & $\mathrm{R}$ & $\mathrm{S}$ \\
\hline IRBB-51 & $X a 4+x a 13$ & $\mathrm{R}$ & $\mathrm{S}$ & $\mathrm{R}$ & $\mathrm{R}$ & $\mathrm{S}$ \\
\hline IRBB-53 & $x a 5+x a 13$ & $\mathrm{~S}$ & $\mathrm{R}$ & $\mathrm{R}$ & $\mathrm{S}$ & $\mathrm{S}$ \\
\hline IRBB-54 & $x a 5+X a 21$ & $\mathrm{R}$ & $\mathrm{R}$ & $\mathrm{R}$ & $\mathrm{R}$ & $\mathrm{S}$ \\
\hline IRBB-55 & $x a 13+X a 21$ & $\mathrm{R}$ & $\mathrm{R}$ & $\mathrm{R}$ & $\mathrm{R}$ & $\mathrm{S}$ \\
\hline IRBB-59 & $x a 5+x a 13+X a 21$ & $\mathrm{R}$ & $\mathrm{R}$ & $\mathrm{R}$ & $\mathrm{R}$ & $\mathrm{R}$ \\
\hline IRBB-60 & $X a 4+x a 5+x a 13+X a 21$ & $\mathrm{R}$ & $\mathrm{R}$ & $\mathrm{R}$ & $\mathrm{R}$ & $\mathrm{R}$ \\
\hline IRBB-61 & $X a 4+x a 5+X a 7$ & $\mathrm{R}$ & $\mathrm{R}$ & $\mathrm{R}$ & $\mathrm{R}$ & $\mathrm{R}$ \\
\hline IRBB-62 & $X a 4+X a 7+X a 21$ & $\mathrm{R}$ & $\mathrm{R}$ & $\mathrm{R}$ & $\mathrm{R}$ & $\mathrm{R}$ \\
\hline IRBB-64 & $X a 4+x a 5+X a 7+X a 21$ & $\mathrm{R}$ & $\mathrm{R}$ & $\mathrm{R}$ & $\mathrm{R}$ & $\mathrm{R}$ \\
\hline IRBB-65 & $X a 4+X a 7+x a 13+X a 21$ & $\mathrm{R}$ & $\mathrm{R}$ & $\mathrm{R}$ & $\mathrm{R}$ & $\mathrm{R}$ \\
\hline IRBB-66 & $X a 4+x a 5+X a 7+x a 13+X a 21$ & $\mathrm{R}$ & $\mathrm{R}$ & $\mathrm{R}$ & $\mathrm{R}$ & $\mathrm{R}$ \\
\hline
\end{tabular}

No single BB gene was effective to all the BB pathogen population available in Terai region of Nepal (Table 1). The prevalence of $\mathrm{BB}$ pathogen was highly variable and diverse. IR-24 and Xa14 developed susceptible lesions when inoculated with $\mathrm{BB}$ isolates from all locations. The BB gene Xa21 was effective to isolates from Bardiya, Banke, Kailali and Morang but was susceptible to Rupandehi isolate. The Xal gene showed resistant reaction to Bardiya isolate but was susceptible to the isolates from rest of the locations. Similarly, xal3 was only resistant to Kailali isolate while isolate from other locations produced susceptible lesions. Xa3 did not produce susceptible lesions when inoculated with isolates from Banke, Kailali and Rupandehi. Xa4 was effective to isolates from Bardiya, Kailali and Morang while it was susceptible to isolates from Banke and Rupandehi. Three-, four- and five-gene pyramids were quite effective to the BB isolates collected from all locations, suggesting that their deployment could manage the BB disease in sustainable and durable way. $\mathrm{Xa}$ 7 was effective to $\mathrm{BB}$ isolates of Bardiya and Banke while it was susceptible to those of Kailali, Morang and Rupandehi. The gene xa13 was incompatible to only Kailali isolate. For example, the rice lines IRBB-59, IRBB-60, IRBB-61, IRBB-62, IRBB-63, IRBB-64, IRBB-65 and IRBB-66 were resistant to all isolates (Table 1). 


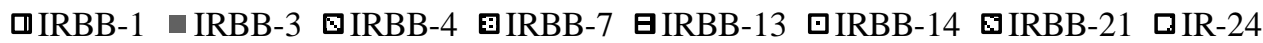

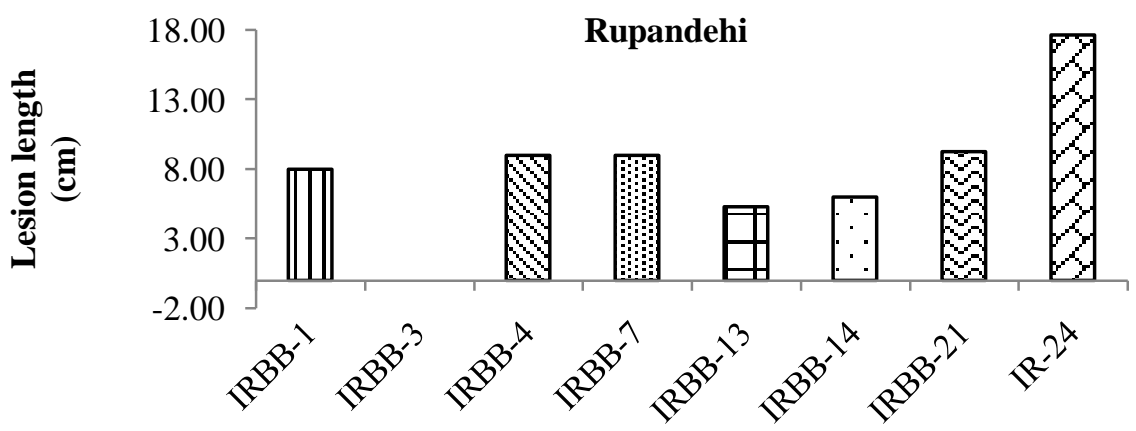

Near isogenic rice lines

Fig. 1:- Development of bacterial blight lesion on near-isogenic lines caused by bacterial blight isolate from Rupandehi at Regional Agricultural Research Station, Khajura, Nepalgunj, Banke, Nepal during 2014

Based on the average lesion length of the three inoculated leaves the highly virulence isolates belonged to Rupandehi group and were virulence to IRRB-1, IRBB-4, IRRB-7, IRBB-13, IRRB-14, IRRB-21 and IR-24 (Fig 1). The longest lesion length was produced in the susceptible line IR-24, possessing Xal8 gene which was ineffective to all isolates (Fig 2). The isolates belonging to Rupandehi was avirulent on genotype IRBB-3 which contains resistant gene Xa3.

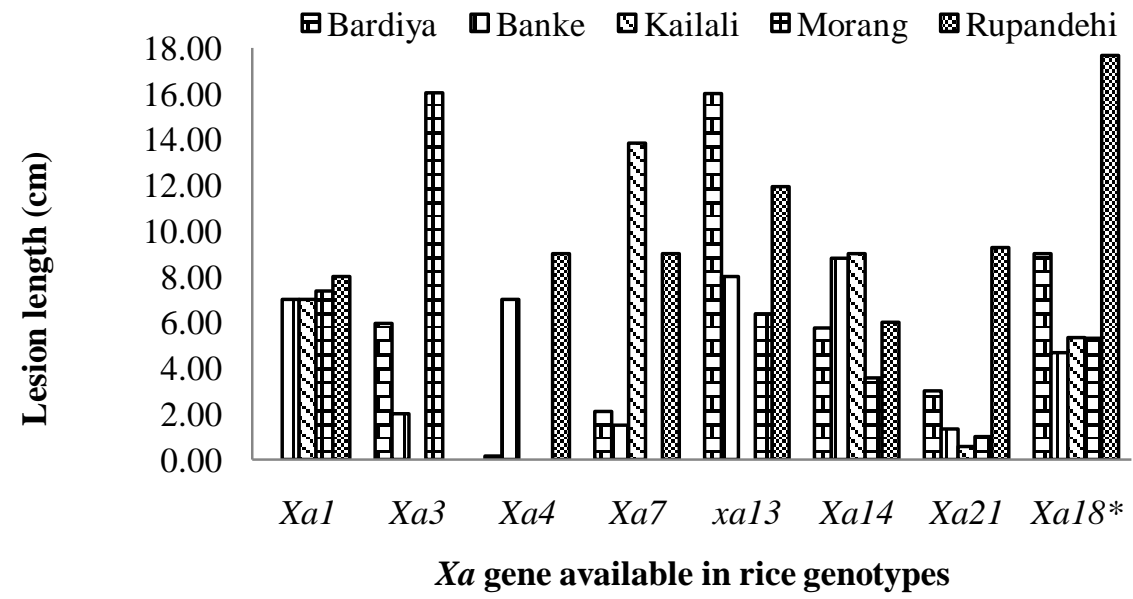

Fig. 1:- Bacterial blight lesion length produced on near-isogenic lines by bacterial blight isolates of different fivelocations at Regional Agricultural Research Station, Khajura, Banke, Nepal during 2014

In the pathogenicity test, the longest lesion length was found in IR-24 genotype when inoculated with the Rupandehi isolates (Fig 1 \& 2). The second longest lesion was developed by the isolates belonging to Morang in IRBB-3 (Fig 2). Isolates belonging to Rupandehi group were found the most aggressive and that of Kailali was the least aggressive.

\section{Conclusion:-}

The result has significant implications for national rice breeding program in deploying resistant source for bacterial blight management. None of the single gene can be expected to control BB in Nepal. Genotypes possessing three and four gene pyramids could be deployed for durable bacterial blight management across the Nepal Terai. Regular monitoring of the pathogen population is also required to deploy location based effective gene(s) for management of BB in Nepal. 


\section{Acknowledgements:-}

The authors are thankful to Regional Director of RARS, Khajura for providing facilities to undertake the study. They also would like to acknowledge the help of staff working at other stations under Nepal Agricultural Research Council in collecting BB infected leaf samples.

\section{References:-}

1. Adhikari T.B. and Mew, T.W. (1994). Resistance of rice to Xanthomonas oryzae pv. oryzae in Nepal. Plant Dis., 78: 64-67.

2. Adhikari T.B., Mew T.W. and Teng, P.S. (1994). Phenotypic diversity of Xanthomonas oryzae pv. oryzae in Nepal. Plant Dis., 78: 68-72.

3. Adhikari T.B. and Mew, T.W. (1991). Effect of bacterial blight on growth and yield of rice in Nepal. J. Inst. Agric. Anim. Sci., 12: 29-40.

4. Adhikari, T.B., Mew, T.W. and Leach, J.E. (1999). Genotypic and pathotypic diversity in Xanthomonas oryzae pv. oryzae in Nepal. Phytopathology, 89: 687-694.

5. Adhikari, T.B., Vera Cruz, C.M., Zhang, Q., Nelson, R.J., Skinner, D.Z., Mew, T.W. and Leach, J.E. (1995). Genetic diversity of Xanthomonas oryzae pv. oryzae in Asia. Appl. Environ. Microbiology, 61: 966-971.

6. Adhikari, T., Leach, J.E. and Mew, T.W. (1996). Bacterial blight of rice and its control in Nepal. Integra. Pest Mange. Rev., 1: 91-95.

7. Adhikari, T.B. and Shrestha, S.M. (1989). Distribution and severity of bacterial blight in Nepal. J. Inst. Agric. Anim. Sci.,10: 31-38.

8. Adhikari, T.B., Ram C.B. and Mew, T.W. (1999). Virulence of Xanthomonas oryzae pv. oryzae on rice lines containing single resistance genes and gene combinations. Plant Dis., 83: 46-50.

9. Chaudhary B., Shrestha, S.M., Singh U.S., Manandhar H.K., Zaidi N.W., Thapa R.B. and Dangal, N.K. (2015). Evaluation of Sub1 and non-Sub1 rice for resistance to bacterial blight using submerged and non-submerged seedlings. Agricultural and biological Sciences Journal, 1(6): 229-234.

10. Dangal N.K., Chaudhary, B., Joshi, P. and Sherpa, A.T. (2014). Evaluation of rice genotypes against bacterial leafblight under field condition. Pages 313-318 in: Proceedings of the 27th National Summer Crops Workshop. Nepal Agricultural Research Council, Kathmandu.

11. Gomez, K.A. and Gomez, A.A. (1984). Statistical procedures for Agricultural research. 2nd ed. John Wiley and Sons, New York.

12. International Rice Research Institute. (1979). Rice disease in north and eastern India, Nepal, Bangaldesh with focus on bacterial blight. International Rice Research Institute, Los Banos, Philippines.

13. Kauffman, H.E., Reddy, A.P.K., Hsieh, S.P.Y. and Merca, S.D. (1973). An improved technique for evaluating resistance of rice varieties to Xanthomonas oryzae pv. oryzae. Plant Dis. Rep., 57: 537- 541.

14. Khadka, B.B., Shah, S.M., and Lawat, K. (1968). Plant disease in Nepal-A supplementary list. FAO Plant Protection .bull. Tech. doc. No 66.

15. Lin, X.H., Zhang, D.P., Xie, Y.F., Gao, H.P. and Zhang, Q. (1996). Identifying and mapping a new gene for bacterial blight resistance in rice based on RFLP markers. Phytopathology, 86: 1156-1159.

16. Manandhar, H.K., Thapa, B.J. and Amatya, P. (1987). Bacterial blight (BB) incidence in hilly regions of Nepal. International Rice Research Newsletter, 12(3): 28.

17. Manandhar, H.K. (1987). Rice diseases in Nepal. Plant Pathology Division, Department of Agricuture/ HMG Nepal and Winrock International, USAID.

18. Mew, T.W. (1987). Current status and future prospects of research on bacterial blight of rice. Annu. Rev. Phytopathol., 25: 359-382.

19. Mew, T.W. (1989). An overview of the world bacterial blight situation. Pages 7-12 in: Bacterial Blight of Rice. International Rice Research Institute, Manila, Philippines.

20. Mew, T.W., Vera Cruz, C.M. and Medalla, E.S. (1992). Changes in race frequency of Xanthomonas oryzae pv. oryzae in response to rice cultivars planted in the Philippines. Plant Dis., 76: 1029-1032.

21. Mew, T.W., Reyes, R.C. and Vera Cruz, C.M. (1989). Screening for bacterial blight resistance in rice. Pages 338341 in: Methods in Phytobacteriology, (Eds.): Z. Klement, K. Rudolph and D.C. Sands. Akademiai, Kiado, Budapest.

22. Ogawa, T., Yamamoto, T., Khush, G.S. and Mew, T.W. (1991). Breeding of near isogenic lines of rice with single genes for resistance to bacterial blight pathogen (Xanthomonas oryzae pv. oryzae). Jpn. J. Breed., 41: 523-529.

23. RARS. (2014). Annual Report (2013-2014), Nepal Agricultural Research Council, Regional Agricultural Research Station, Tarahara, Sunsari, Nepal. 